Cultures de bêtes... Outils qui pensent?

\title{
L'intelligence artificielle : un société d'ordinateurs ?
}

\section{Robert Cresswell}

\section{(2) OpenEdition \\ 1 Journals}

Édition électronique

URL : https://journals.openedition.org/tc/577

DOI : $10.4000 /$ tc. 577

ISSN : 1952-420X

Éditeur

Éditions de l'EHESS

\section{Édition imprimée}

Date de publication : 1 novembre 1995

ISSN : 0248-6016

\section{Référence électronique}

Robert Cresswell, «L'intelligence artificielle : un société d'ordinateurs? », Techniques \& Culture [En ligne], 23-24 | 1995, mis en ligne le 09 décembre 2005, consulté le 29 septembre 2022. URL : http:// journals.openedition.org/tc/577 ; DOI : https://doi.org/10.4000/tc.577

Ce document a été généré automatiquement le 29 septembre 2022.

Tous droits réservés 


\section{L'intelligence artificielle : un société d'ordinateurs?}

Robert Cresswell 